\title{
Indicators to Evaluate the Institutional Effectiveness of National Climate Financing Mechanisms
}

\author{
Muhammad Sheriffdeen ${ }^{1}$, Dodik Ridho Nurrochmat ${ }^{2,}$, Perdinan ${ }^{3}$, and Monica Di Gregorio 4 \\ ${ }^{1}$ Graduate Program of Natural Resource and Environmental Management, IPB University Bogor, West \\ Java, Indonesia and Department of Geography and Environmental Management, University of Ilorin, \\ Ilorin Nigeria; muhammad_sheriff@apps.ipb.ac.id \\ 2 Department of Forest Management, Faculty of Forestry and Environment, IPB University Bogor, West \\ Java, Indonesia; dnurrochmat@apps.ipb.ac.id \\ 3 Department of Geophysics and Meteorology, Faculty of Mathematics and Natural Sciences, IPB \\ University Bogor, West Java, Indonesia; perdinan@apps.ipb.ac.id \\ 4 Sustainability Research Institute, School of Earth and Environment, University of Leeds, UK; \\ m.digregorio@leeds.ac.uk \\ * Correspondence author: dnurrochmat@apps.ipb.ac.id; Tel.: +62-81314845101
}

\begin{abstract}
Over the past few decades, tackling climate change has persistently featured in international discussions, with the main issues centring on mobilising adequate global response and effectively coordinating and channelling this response at the sub-national levels. In order to effectively mobilize and harmonize resources to address climate change at country level, the idea of establishing national climate finance institutions (NCFIs) with the duty to mobilise, manage and allocate funds to implement climate change actions has gained prominence among developing countries. This study develops an indicator-based framework to evaluate the institutional effectiveness of the Indonesian Climate Change Trust Fund (ICCTF) as a case study. Building on previous frameworks and principles of climate finance, a total of 21 indicators were identified, these indicators were categorized into five effectiveness components, which are: were identified, and these indicators were categorized into five effectiveness components, which include: legal and regulatory framework, fund mobilization and sustainability, fund management and allocation, monitoring and evaluation, and transparency and accountability. We find that the major and fundamental weakness of the ICCTF is its inability to adequately mobilize funds, while its strength is in management and allocation of available resources. Inclusion of the legal and regulatory framework component, which has been largely absent in previous studies, further enabled us to identify critical legal gaps in the operationalization of the ICCTF. While the current legal foundation of the ICCTF ensures transparency and accountability, it significantly constrains the ICCTFs flexibility and innovative potentials.
\end{abstract}

Keywords: Climate governance, policy, trust funds, finance readiness, ICCTF

\section{Introduction}

Climate change, over the past decades has been recognized as a major environmental and developmental challenge. With impacts spread globally, climate change could undermine global progress against hunger, poverty, inequality and other basic developmental challenges (Moss et al., 2013; Preston et al., 2015; Olazabal et al., 2019). Concerning the challenges, additional investments are required to fight against climate change globally. It was estimated that annual infrastructure investments estimates in excess of between USD700 billion and USD5 trillion by 2030 are likely to be required to achieve the Paris Agreement goals (Kotchen and Costello, 2018). The Paris Agreement sets out ambitious pathways for climate change mitigation and adaptation, including pledges to support poor and developing nations by providing USD100 billion per annum by 2020 through public, private and other innovative sources (Lesnikowski et al., 2017). The support to developing countries was made considering the adverse impacts of climate change are mostly felt by developing countries whose contributed less to $\mathrm{CO}_{2}$ emissions (Schipper, 2007; Ayers and Dodman, 2010; Ayers et al., 2014), particularly through a better land use management (Sahide et al., 2015; Erbaugh and Nurrochmat, 2019; Nurrochmat et al., 2020).

The required climate change investments are generally targeted to control greenhouse gases emissions through climate change mitigation programs and to reduce vulnerability and build 
resilience especially in developing nations through climate change adaptation programs (Bours et al., 2015; Ford et al., 2015; Haasnoot et al., 2018). The investments should also be mainstreamed into country-level policies, programs and actions. Climate Change Financial Framework (CCFF) (Nicholson, et al., 2017) emphasizes the need to align country policies on climate change with the existing public economic and financial management systems to establish proper mobilization and management of climate change finance. This alignment will ensure the investment target of utilizing the financing flows to manage the consistency of development programs with the low-carbon and climate-resilient development pathways.

With a consideration to the CCFF measures, the establishment of an institution to manage climate change funds are required recognizing the increasing global availability of finance for climate change actions from public, private and innovative sources. The institution should be mandated to access and manage the funds in the most efficient and effective manner (Nicholson, et al., 2017) in order to enhance the confidence of investors and donors through more transparent, risk-informed plans and budgets. This establishment of a financial institutional, which is capable of adequately mobilizing, managing, and distributing fund for climate change mitigation and adaptation programs in a sustainable and transparent manner, is particularly a big challenge for developing countries (Denton, 2010; Chaum et al., 2011). To address this issue, developing countries have started to establish national climate finance institutions (NCFIs), also called National Climate Funds (NCFs), to spearhead national governance of climate change (Flynn, 2011; Watson and Shalatek, 2019). NCFIs are mechanisms aimed at enabling governments to strengthen their bureaucratic and financial systems through aligning and harmonizing international policies and resources towards achieving national climate change objectives. Ensuring that these institutions operate effectively and hence maximizing their impacts is therefore of utmost importance in achieving desired outcomes (Chaum et al., 2011; Grüning et al., 2012).

Although several frameworks and methods to evaluate country level effectiveness and capacity regarding climate governance and investments have been developed (e.g. Brooks et al., 2011; Bird et al., 2013; Nakhooda, 2013; Schalatek and Bird, 2016; Samuwai and Hills, 2018), it is still necessary to develop an approach to evaluate the effectiveness of NCFIs. This study was focused to develop a method completed with its indicators to analyze the effectiveness of NCFIs. The developed method was then applied to assess the effectiveness of the main national climate change financial institution in Indonesia, The Indonesian Climate Change Trust Fund (ICCTF).

While effectiveness can vary widely in meaning, this study draws relevant literatures to construct indicators to measure the institutional effectiveness. The effectiveness measurement will provide information on the capacity of national climate finance institutions to attract and adequately manage climate finance, as well as monitor and evaluate its impacts (Bird et al., 2013; Schalatek and Bird, 2016). We begin by reviewing the evolving context and objectives upon which NCFIs operate. We then identify the key indicators of effectiveness of NCFI.

\subsection{The Role of National Climate Finance Institutions in Climate Finance Delivery}

A fundamental component of the international response towards climate change is making available new and additional funding to support climate change action in the world's most vulnerable countries. As a result, the international community pledged to make available USD100 billion per year by 2020 through public, private and other innovative sources. As at present, there are over 50 global public funds, 100 multi- and bilateral climate funds as well as 60 separate carbon markets, and 6000 private equity funds (Vandeweerd et al., 2014; Samuwai and Hills, 2018). To ensure better access and efficient utilization of these funds, many countries have developed national climate funds or NCFIs (Flynn, 2011; Rai et al., 2015).

NCFIs are mechanisms that enable countries to better assemble and direct financial resources towards climate change mitigation and adaptation programs (Grüning et al., 2012). As country 
driven mechanisms, they help to better coordinate national climate change activities while also strengthening national systems and institutions to promote sustainable development and aid effectiveness. According to Flynn (2011), the main goals of an NCFI are to gather, blend, coordinate and also enhance national ownership of climate finance. Although funding mechanisms exist within the United Nations Framework Convention on Climate Change (UNFCCC), they are largely limited to financial resources under the Clean Development Mechanism (CDM). In such a situation, an NCFI can be more effective as it is able to attract a wider variety of climate finance either as implementing entities of larger multilateral funds like the Adaptation fund or through private partnerships as well as innovative funds (Vandeweerd et al., 2014).

$\mathrm{NFCls}$ in many instances exists as trust funds, which are legal agreements whereby an organization, individual or a group (trustee) legally acquires and manages funds or property from a donor exclusively for a specified purpose or beneficiary as defined in the agreement or deed of trust (Irawan et al., 2012; Rai et al., 2015). Where legal provisions do not support the establishment of a trust, foundations and civil associations are often employed for the same purpose (Spergel and Taieb 2008; Bladon et al., 2014). Whichever legal form is chosen to establish them, NCFIs are for the most part independent entities having an independent legal status, although government representatives often sit on their governing bodies (Smyth, 2009; Bladon et al., 2014). The governing body, consisting of a board of trustee or steering committee, technical committees and a secretariat is largely comprised of both private and public stakeholders (Spergel and Taieb, 2008). The board maintains fiduciary controls by providing strategic direction and overseeing the approval and transfer of funds, while the secretariat coordinates daily bureaucratic activities (Irawan et al., 2012).

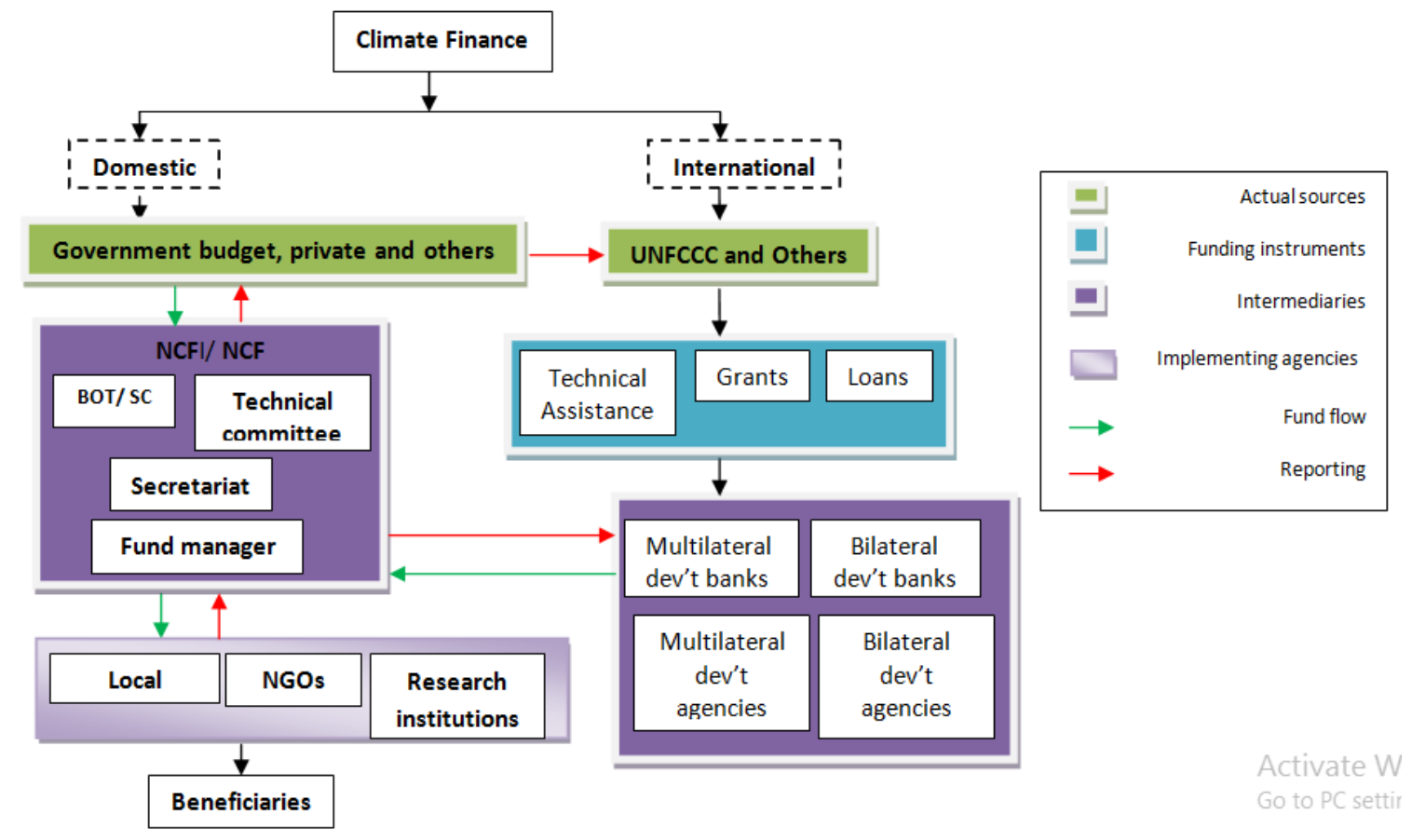

Figure 1. Role of NCFIs in climate finance distribution

While fiduciary standards of some NCFIs such as the National Environment Fund of Benin may differ by donor, project or implementer, other funds like the ICCTF have strictly outlined fiduciary guidelines in accordance with the Indonesian national fiduciary policies applicable across all projects (Watson and Schalatek, 2019).The ICCTF is believed to be the earliest example of a national climate fund, although the Brazilian Amazon Fund is known to be the largest with a capitalization of over USD1 billion from Norway. There are also national climate change funds in Bangladesh, Benin, Cambodia, Ethiopia, Guyana, the Maldives, Mali, Mexico, the Philippines, Rwanda, and South Africa, 
and more countries are also expected to establish national climate finance institutions in the nearest future (Watson and Schalatek, 2019). Figure 1 illustrates the role of a NCFI in national climate finance administration.

\subsection{The Effectiveness of National Climate Finance Institutions}

The need to ensure adequate access and utilization of available global resources to achieve required climate change responses has resulted in an increased interest in climate finance effectiveness (Buchner et al., 2012; Ellis et al., 2013). Though evaluating climate finance effectiveness can and has commonly been done based on outcome, it can also be done by assessing the capacity of national institutions (Ford et al., 2013; Nakhooda, 2013; Nakhooda, et al., 2014; Bird et al., 2016). This aspect of climate finance effectiveness is also referred to as "climate finance readiness" (Vanderweerd et al., 2013; Sumawai and Hill, 2018). We however preferred the term "effectiveness" in this study due to possible country-wide implication of the former.

While empirical literature on NCFIs and their effectiveness remains relatively scarce, the 2005 Paris Declaration on Aid Effectiveness and other international agreements recognize the importance to ensure aid effectiveness (Bird et al., 2013; Nakhooda, 2013). These agreements and methodologies developed to implement them, set forth a range of principles and criteria to measure effectiveness of institutions and processes involved in aid utilization. According to Glemarec (2011), the main factors that shape the institutional design and focus of national climate or development funds include the local economic and political landscape, national climate change and development priorities as well as existing capacity within government ministries and agencies. As a result, institutional structures of NCFIs differ to a great extent according to national circumstances and priorities (Flynn, 2011). Nevertheless, in their configuration and operations, NCFIs generally conform with international principles recognized both in the Paris Declaration on Aid Effectiveness and the Accra Agenda for Action (AAA) such as harmonization and coordination, national ownership or alignment with national priorities and inclusive partnerships in achieving development results and accountability (Irawan et al., 2012).

To analyze the effectiveness of multilateral climate funds, Nakhooda (2013) proposed a framework based on literature on development aid and climate finance effectiveness which considers the objectives and historical context of multilateral climate funds. It identified two aspects of effective fund governance: spending and outcomes. Each has five components: mobilization, governance, allocation, disbursement and monitoring and evaluation for an effective spending and scales, enabling environments, innovation and national ownership. Another framework proposed by Bird et al. (2013) consist of criteria and indicators drawn from the international climate and corporate finance principles to indicate what climate finance delivery should look like in an ideal world. This approach is based on a methodology developed by the United Nations Development Programme (UNDP) and employed in Asia in a series of country studies to analyze the administration and delivery of climate finance at the sub-national level.

The framework identifies the three criteria of coordination, capacity to change and capacity to innovate to assess effective delivery of sub-national climate change finance. Other frameworks build on the principles of the UNFCCC regarding climate change finance, such as additionality, equity, ownership and transparency with the addition of a human rights perspective (Schalatek and Bird 2016; Richards and Shalatek, 2017). These frameworks are relevant to the climate finance literature as they help to offer an evidence-based outline of the operations and effectiveness of climate investments and initiatives and recognize key bottlenecks. However, some are mainly applicable at a national scale, while others are too complicated to assess individual institutions, and others lack comprehensiveness. 


\subsection{Framework for Evaluating Effectiveness of National Climate Finance Institutions}

Albeit global resources to tackle climate change are becoming increasingly available, resources are still far from what is required to meet global targets, hence the need to ensure adequate capacity of systems and institutions to manage climate expenditures (Preston et al., 2015; Bird et al., 2016). In this context, effectiveness is a measure of performance defined by an identified objective and determined within a particular setting (Ellis et al., 2013). An evaluation of institutional effectiveness therefore helps to understand the capacity (or lack of it) of climate finance institutions to achieve the objectives they are established for.

Building on fundamental climate finance components, such as mobilization, allocation, monitoring and evaluation, and principles of aid effectiveness, this framework identifies 21 indicators from an extensive literature on climate finance, aid effectiveness, management, and organizational studies. These indicators fall under five distinct but intimately linked components namely: legal and regulatory framework, fund mobilization and sustainability, fund allocation and governance, transparency and accountability, and monitoring and evaluation.

The uniqueness of this framework is the identification and inclusion of the legal and regulatory framework as an important component in understanding and measuring effectiveness of countrylevel climate finance institutions (Morita and Pak, 2018), which to the best of our knowledge has rarely been considered in previous works. This framework also considers the required institutional capacity contained in the fiduciary standards of the Adaptation Fund (AF) for accrediting National Implementing Entities (NIEs). Note should be taken that this framework does not aim to provide a comprehensive evaluation of NCFIs, but to rather provide national policy makers with an overview of existing policy gaps and areas that need further efforts, thereby enabling adequate rearrangements and amendments in an integrated manner. Figure 2 shows the five components for measuring the effectiveness of national climate finance institution.

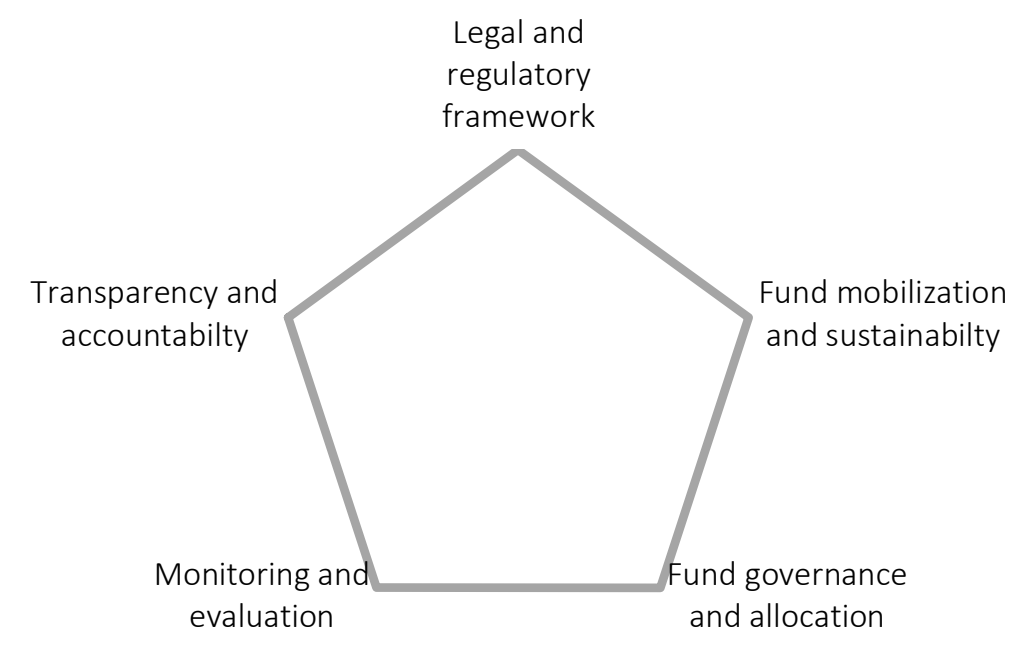

Figure 2. The five components of proposed indicators for measuring the effectiveness of national climate finance institution.

\subsubsection{Legal and Regulatory Framework}

Numerous studies assert that increased flow of and access to both public and private capital especially to and within developing countries is of utmost importance for effective mitigation and adaptation to climate change (Barrett, 2013; Fankhauser and Burton, 2011). To generate and effectively manage the required scale of financial resources, it is vital that national institutions have sound legal and regulatory frameworks that will enable adequate mobilization, harmonization and alignment of public and private climate finance (Gupta et al., 2010; Morita and Pak, 2018; Bowman and Steenmans, 2019). It should be noted that although the establishment of NCFIs is usually backed 
by laws or decrees in most countries, this does not necessarily translate to having all the legal requirements or capacity to function properly (Morita and Pak, 2018). In their report titled "Climate finance law: legal readiness for climate finance", Bowman and Steenmans (2018; p. 7) noted that "a robust and transparent domestic legal system is key to attracting both public international funds and private sector finance, yet the legal systems of many developing countries do not yet align well with the needs of public or private financiers".

This is also emphasized in the required fiduciary standards of the Adaptation Fund (AF) for accrediting national implementing entities, which require "legal status to contract with the Adaptation Fund and third parties". Effective legal and regulatory frameworks will enhance the flow of climate finance in that it ensures accountability, transparency and clarity by regulating and shaping procedures and responsibilities of multiple stakeholders involved in climate change governance (Irawan et al., 2012; Bowman and Steenmans, 2018). An effective legal and regulatory framework of a NCFI can be operationalized through these indicators: (a) clarity of laws and regulations (b) non- contradictory or overlap with other institutions (c) enable maximum and efficient mobilization of fund (d) allow efficient disbursement and allocation, and (e) enhance transparency and accountability (Table 1 ).

\subsubsection{Fund mobilization and sustainability}

Resources or capital in the form of funds is an important aspect of an institution and no doubt influences the effectiveness of a climate finance institution, which is largely dependent on its ability to mobilize funds (Mendelsohn and Nordhaus, 1999; Nelson et al., 2010; Gupta et al., 2010). This has been particularly emphasized at various international conventions, such as the Bali Action Plan emphasized that finance for climate change mitigation and adaptation must be adequate, predictable, sustainable, as well as provide additionality, for effective transformation towards a sustainable future. Another aspect of effective fund mobilization of a climate finance institution is innovation, this is necessary as conventional public and private sources of funds may sometimes be unreliable (Tippman et al., 2013; Schalatek and Bird, 2016). The identified criteria for effective fund mobilization and sustainability are therefore; (a) known and secured sources of funds (b) funds are sourced from all possible sources (c) Innovation (d) additional and increasing.

\subsubsection{Fund governance and allocation}

Mobilized funds, regardless of how abundant, require adequate management, and in this regard, fund governance and allocation has to do with the capacity to manage and distribute climate funds adequately and efficiently, and that the decision making processes involved is especially crucial as it is found to impact donor confidence (Tippman et al., 2013; Vij et al., 2017). To adequately and efficiently manage resources or funds, relevant stakeholders must be represented in the decision making processes in an equitable and fair manner (Fankhauser and Burton, 2016). Also, in line with the primary purpose of national climate finance institutions as mechanisms that supports and enhance country owned climate change policies and actions, national climate change policies or priorities should be reflected in the decision making processes of national climate finance institutions to promote ownership, and minimize contradictory and redundant policies (Butler et al., 2014; Di Gregorio et al., 2017; Weiler et al., 2018). The identified indicators for this component are; (a) equitable and fair representation of stakeholders (b) independence from donor interest or pressure (c) adequate capacity and skill to manage climate fund (d) easy access for the most vulnerable, and (e) supports national climate change goals.

\subsubsection{Monitoring and evaluation}

As international interest to invest on climate change mitigation and adaptation increased through the pledge of USD100 billion annually by the year 2020, it becomes imperative to monitor and evaluate output against input. Monitoring and evaluation is a learning process for institutions, 
it holds a key role in understanding what works and what does not, and how to learn from experience in order to improve outcomes (Lamhauge et al., 2013).Due to the complex and case specific nature of monitoring and evaluation, the scope of the monitoring and evaluation component in this study is only to indicate whether monitoring and evaluation is effective or not. The indicators for that are: (a) monitoring and evaluation is participatory (b) monitoring and evaluation is timely (c) monitoring and evaluation is carried out at all levels.

\subsubsection{Accountability and transparency}

Accountability and transparency are two distinct but strongly related terms. Accountability according to Smyth (2011, p 108) is "a state of affairs in which some actors have the right to (a) hold other actors to a set of standards, (b) judge whether those actors have fulfilled their responsibilities in light of these standards, and (c) impose sanctions if they determine that these responsibilities have not been met". In simpler terms, it is a way by which authorities are made answerable for their actions (Biermann and Gupta, 2011; Dore and Lebel, 2010). Transparency on the other hand is a voluntary or obligatory action that enables accountability. These actions may be in form of public disclosure and enabling full access to information about procedures and key decisions of an institution (Lebel et al., 2017).

Accountability and transparency enhance legitimacy and create an incentive for better performance (Bernstein, 2005). This component is operationalized as: (a) timely and public disclosure of all earnings and spending (b) transparent allocation and disbursement procedures (c) existence of a complaint and feedback system. Table 1 presents a tabular summary of the identified components and their indicators based on literature review.

Table 1. Identified components, their indicators and references from the literature

\begin{tabular}{|c|c|c|}
\hline Criteria & Reference & Indicators \\
\hline \multirow[t]{5}{*}{ Legal framework } & $\begin{array}{l}\text { Irawan et al., 2012, Norris, 2000, } \\
\text { Moritaand Park, } 2019\end{array}$ & $\begin{array}{l}\text { Clarity of laws and regulations governing the } \\
\text { fund }\end{array}$ \\
\hline & $\begin{array}{l}\text { Denton, 2010; Flynn, 2011, Irawan et al., } \\
2012\end{array}$ & $\begin{array}{l}\text { Laws and regulations are not contradictory or } \\
\text { overlap with other institutions }\end{array}$ \\
\hline & $\begin{array}{l}\text { Bladon et al., 2014, Bowman and } \\
\text { Steenmans, 2018; 2019, Tippman et al., } \\
2013\end{array}$ & $\begin{array}{l}\text { Laws enable maximum and efficient mobilization } \\
\text { of funds }\end{array}$ \\
\hline & $\begin{array}{l}\text { Bladon et al., 2014, Bowman and } \\
\text { Steenmans, 2018; } 2019\end{array}$ & Laws allow efficient disbursement and allocation \\
\hline & $\begin{array}{l}\text { Norris, 2000, Irawan et al., 2012, } \\
\text { Moritaand Park, } 2018\end{array}$ & $\begin{array}{l}\text { Laws and regulations enhance transparency and } \\
\text { accountability of the ICCTF }\end{array}$ \\
\hline \multirow[t]{4}{*}{$\begin{array}{l}\text { Fund mobilization } \\
\text { and sustainability }\end{array}$} & $\begin{array}{l}\text { Schalatek and Bird, 2016; Samuwai and } \\
\text { Hills, } 2018\end{array}$ & $\begin{array}{l}\text { Sources of fund are known and secured over } \\
\text { long term funding cycle. }\end{array}$ \\
\hline & $\begin{array}{l}\text { Tippman et al, 2013; Peters et al., 2012; } \\
\text { Bird et al., 2013; Bladon et al., } 2014\end{array}$ & Innovation in sourcing funds \\
\hline & $\begin{array}{l}\text { Christiansen et al., 2012, Tippman et al., } \\
\text { 2013, Samuwai and Hills, } 2018\end{array}$ & Funds are sourced from all possible sources \\
\hline & $\begin{array}{l}\text { Bladon, } 2014 \text {, Norman and Nakhooda, } \\
\text { 2015, Heinetal., } 2018\end{array}$ & Funds and their sources are increasing \\
\hline \multirow[t]{4}{*}{$\begin{array}{l}\text { Fund allocation and } \\
\text { governance }\end{array}$} & $\begin{array}{l}\text { Fankhauser and Burton, 2016, Vijetal., } \\
2017\end{array}$ & Equitable and fair representation of stakeholders \\
\hline & $\begin{array}{l}\text { Molenaers et al, 2015, Weiler et al., } \\
2018\end{array}$ & Independence from donor interest/pressure \\
\hline & $\begin{array}{l}\text { Vandeweerd,et al., 2014; Tippman et al., } \\
\text { 2013; Vij et al, 2017; Adaptation fund, } \\
2017\end{array}$ & $\begin{array}{l}\text { Adequate capacity and skill to manage climate } \\
\text { fund }\end{array}$ \\
\hline & $\begin{array}{l}\text { Adgers et al, 2009; Nelson et al., 2010; } \\
\text { Fankhauser and Burton, 2016; Barrett, } \\
2013\end{array}$ & Easily accessible to the most vulnerable \\
\hline
\end{tabular}




\begin{tabular}{lll}
\hline & $\begin{array}{l}\text { Ayers and Dodman 2010; Runhaar et al., } \\
\text { 2014; Scobie 2016; Paulus and } \\
\text { Hindmarsh, 2016 }\end{array}$ & $\begin{array}{l}\text { Supports and align with national climate change } \\
\text { priorities }\end{array}$ \\
$\begin{array}{l}\text { Monitoring and } \\
\text { evaluation }\end{array}$ & $\begin{array}{l}\text { Adger, 2005; Faulkner et al, 2015; } \\
\text { Douxchamps et al., 2017 }\end{array}$ & $\begin{array}{l}\text { Monitoring and evaluation of projects is } \\
\text { participatory }\end{array}$ \\
& $\begin{array}{l}\text { Faulkner et al., 2015; Bladon, 2014; } \\
\text { Douxchamps et al., 2017 }\end{array}$ & Monitoring and evaluation exercise is timely \\
& $\begin{array}{l}\text { Di Gregorio et al., 2019; Adger, 2001; } \\
\text { Adger et al., 2005 }\end{array}$ & $\begin{array}{l}\text { Monitoring and evaluation is carried out at all } \\
\text { levels }\end{array}$ \\
$\begin{array}{l}\text { Accountability and } \\
\text { transparency }\end{array}$ & $\begin{array}{l}\text { Fox, 2007; Dore and Lebel, 2010; Lebel, } \\
\text { 2017 }\end{array}$ & $\begin{array}{l}\text { Timely and public disclosure of all earnings and } \\
\text { spending }\end{array}$ \\
\hline & $\begin{array}{l}\text { Fox, 2007; Dore and Lebel, 2010; Hanger } \\
\text { et al., 2013; Lebel, 2017 }\end{array}$ & $\begin{array}{l}\text { Transparent allocation and disbursement } \\
\text { procedures. }\end{array}$ \\
\hline $\begin{array}{l}\text { Gupta and Mason, 2016; Mehrotra, } \\
\text { 2006; }\end{array}$ & $\begin{array}{l}\text { Public voice or complaint and feedback system } \\
\text { Fox, 2007; Hanger et al., 2013 }\end{array}$ & $\begin{array}{l}\text { Public access to information for independent } \\
\text { evaluation }\end{array}$ \\
\hline
\end{tabular}

\section{Materials and Methods}

This research design of the study involved five main steps: (1) the formulation of the proposed framework through a review of relevant literature and materials; (2) the formulation of a semistructured questionnaire based on the indicators of the framework; (3) the conduct a reliability test of the questions; (4) the determination of an appropriate qualitative analytical tools to analyze acquired data and lastly; (5) the selection and contact of key-respondents.

\subsection{Analytical tools}

The qualitative analysis technique employed in this study is a multi-criteria decision making (MCD) tool adapted from (Ameyaw and Chan, 2015; Liu et al.,2013; Owusu et al., 2020). The method has been widely utilized in various fields to assess and analyze decision making in areas of project performance evaluation, health risk and project risk assessment and allocation (Owusu et al., 2020). It involves the following steps:

i. Define the scale of scoring and measurement for the criteria and indicators; $E=\left\{e_{1}, e_{2}, e_{3}, \ldots e_{n}\right\}$. In this study we used a five point Likert scale, where $e_{1}=$ very weak, $e_{2}=$ weak, $e_{3}=$ fair, $e_{4}=$ good, $e_{5}=$ very good.

ii. The weightings $(\boldsymbol{\omega})$ for each indicator i.e. $\omega_{i}=\left\{\omega_{1}, \omega_{2}, \ldots, \omega_{m}\right\}$ is computed by normalizing the mean scores of the indicators:

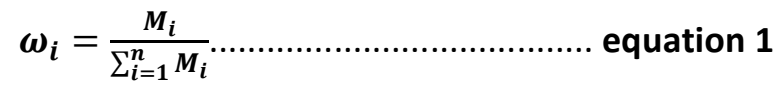

Where, $\boldsymbol{M}$ is the mean score of an indicator and $0 \leq \boldsymbol{\omega} \leq 1$

iii. Establish the membership value $(\boldsymbol{D})$ of each component by matrixing the indicator weights of each component against the indicator membership scores as assigned by the respondents: $\mathrm{D}=\boldsymbol{\omega}_{i}{ }^{*} \mathrm{R}_{\mathrm{i} \mathrm{j}}$ equation 2

Where, $\mathbf{R}$ is a matrix containing the indicator membership scores assigned by the key persons

iv. Derive the index score (I) of each component by summing the products of component membership values and the measuring scale, using equation;

$I=\sum_{i=1}^{5} D \times E$. equation 3

Where, $\mathbf{E}$ is the scoring scale used, i.e. $1-5$, and $(1 \leq \mathrm{I} \leq 5)$

\subsection{Cronbach's reliability test}

A reliability test is an important element in the evaluation of a measurement instrument, as it adds legitimacy and precision to the analysis of research data (Tavakol and Dennick, 2011). In this 
study, we used the Cronbach's alpha, which is the most commonly used tool for testing reliability. The Cronbach's reliability test was carried out for each of the five components in this study, and the results are presented on Table 2.

Table 2. Results of Cronbach's alpha for reliability

\begin{tabular}{lc}
\hline Component & $\begin{array}{c}\text { Cronbach'salpha for } \\
\text { reliability }\end{array}$ \\
\hline Legal andregulatoryframework & 0.783 \\
Fund mobilizationandsustainability & 0.769 \\
Fund governanceandallocation & 0.711 \\
Monitoring andevaluation & 0.794 \\
Accountabilityandtransparency & 0.825 \\
\hline
\end{tabular}

Table 2 shows that all the components have quite high reliability scores considering the general rule of thumb that the acceptable reliability score starts from 0.7.

\subsection{Case-study: The Indonesian Climate Change Trust Fund (ICCTF)}

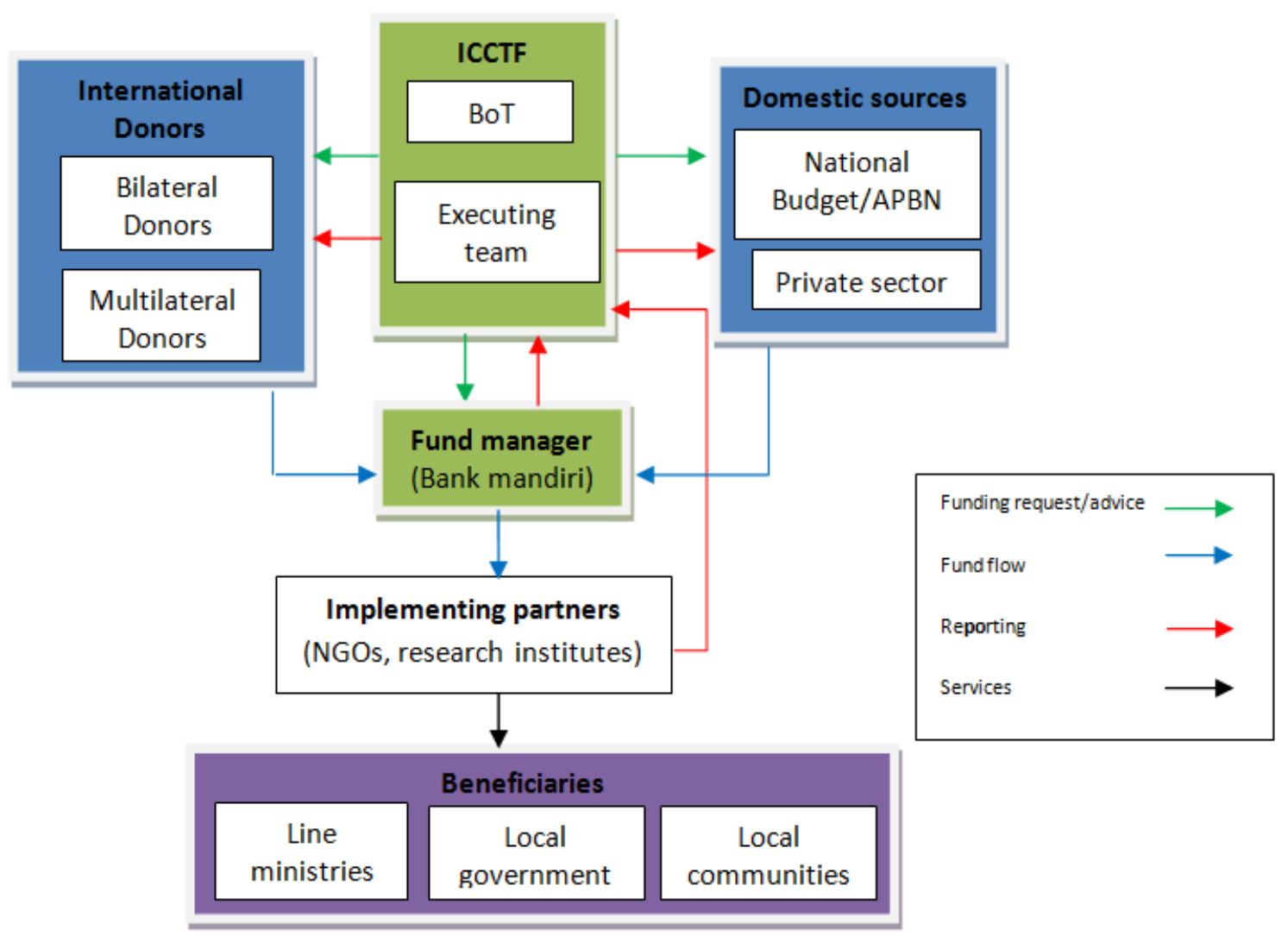

Figure 3. Operational and funding flow of the ICCTF

Shortly after Indonesia announced its ambitions to reduce emissions by $26 \%$ in 2009 , the Indonesian Government released a ministerial decree establishing the Indonesia Climate Change Trust Fund (ICCTF) as a key institution in Indonesia's climate change architecture that leads the way to achieve Indonesia's goals of a low carbon economy and greater resilience to climate change. The ICCTF's main aim is to support the Indonesian Government in achieving its mitigation and adaptation targets, through funding the implementation of national and local mitigation and adaptation actions 
in line with the national developmental plan. Figure 3 describes the operational and funding flow of the ICCTF.

The ICCTF is funded mainly through the annual budget and from foreign donors in form of grants. Since its establishment in 2009, the ICCTF has managed funds from the national budget and overseas grants amounting to billions of rupiahs, providing funding for climate change mitigation and adaptation projects across Indonesia. The ICCTF is made up of a steering committee or board of trustees, a technical committee, a secretariat and a fund manager.

\subsection{Key Respondents' Selection}

The selection of key informants involved two steps. The first stage was a purposive selection of key informants from various institutions with known relevance to or association with the ICCTF. The second step included self-identification to identify the most suitable persons by asking key informants to rate their own level of knowledge on the ICCTF and its operations on a scale of 0 to 5 (lowest to highest). Persons with knowledge levels of 4 to 5 were then selected for the final study. Fifty (50) key informants were initially identified and involved in the first stage, out of which thirtyone (31) were finally selected (Table 3).

Table 3. Respondents by institutions

\begin{tabular}{|c|c|c|c|}
\hline Sector & Percentage (\%) & Institution & $\begin{array}{r}\text { Number of } \\
\text { Respondents }\end{array}$ \\
\hline \multirow[t]{3}{*}{ Public service } & 45 & ICCTF & 8 \\
\hline & & $\begin{array}{l}\text { Ministry of national } \\
\text { development planning } \\
\text { (Bappenas) }\end{array}$ & 2 \\
\hline & & $\begin{array}{l}\text { Ministry of environment and } \\
\text { forestry (KLHK) }\end{array}$ & 4 \\
\hline Private sector & 13 & Non-specific & 4 \\
\hline \multirow[t]{3}{*}{ Academics } & 19 & IPB University (Senior lecturer) & 3 \\
\hline & & IPB University (PhD students) & 2 \\
\hline & & IPB University (Master student) & 1 \\
\hline \multirow{3}{*}{$\begin{array}{l}\text { Civil society/ } \\
\text { NGO }\end{array}$} & 23 & UNDP & 1 \\
\hline & & USAID & 1 \\
\hline & & Local NGOs & 5 \\
\hline Total & 100 & & 31 \\
\hline
\end{tabular}

\section{Results}

The result of multi-criteria decision analysis is displayed on Appendix 1. It shows the mean scores of all indicators as ranked by the respondents, as well as the weight of all indicators relative to their components and the eventual index scores of each component. To enhance better understanding of our results Figure 4 shows a radar view of ICCTFs effectiveness components based on their index scores (see appendix 1). Detailed discussion of the result on each component is made from subsection 3.1 to 3.5 . 


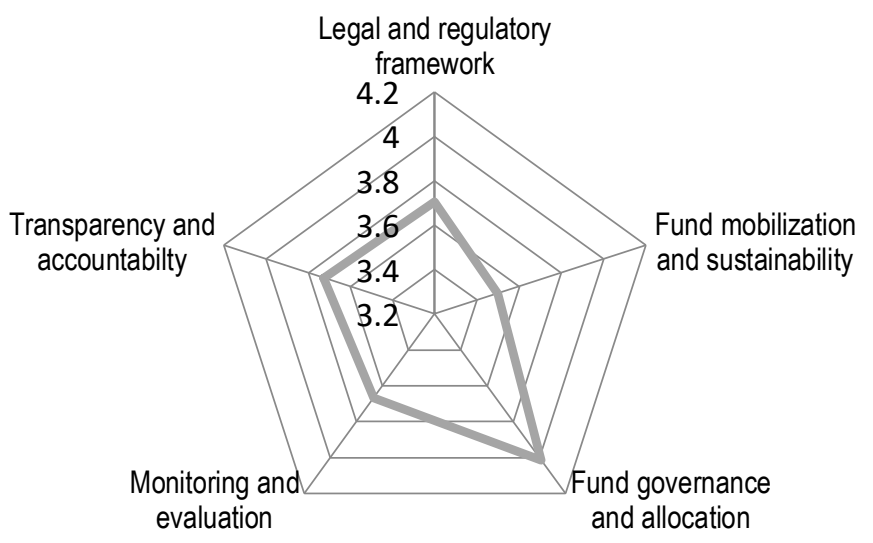

Figure 4. Index scores of the effectiveness components of ICCTF

\subsection{Legal and regulatory framework}

A number of studies have established the significance of an adequate legal and regulatory framework for effective climate change governance, especially in developing nations (Bowman and Steenmans, 2018; 2019; Irawan et al., 2012; Sumawai and Hills, 2019). As shown in Figure 4, the legal and regulatory framework ranked as the third most effective component out of the five components identified in this study with an index score of 3.70. Among the five indicators for the legal and regulatory framework of the ICCTF, enhancing transparency and accountability presented the highest mean score (4.13). This is followed by in the score on enabling maximum and efficient fund mobilization (3.29). Other indicators such as enabling maximum and efficient disbursement, non-overlap of laws and regulations and clarity of the laws and regulation have mean scores of 3.42, 3.58 , and 3.97 respectively. The indicators on how the legal and regulatory framework enables efficient fund mobilization and fund disbursement were perceived as the two weakest. According to some respondents the obligation for ICCTF to abide to the rigid financial regulations of the Indonesian national government for all grants and funds, makes it difficult to maintain the flexibility in regulatory financial structures needed to address climate change.

\subsection{Assessing fund mobilization and sustainability}

The fund mobilization and sustainability component comprising of four indicators ranked fifth out of the five components identified (see appendix 1). Out of the four indicators, "known and secured long term funding" which indicates the stability and sustainability of funding for the ICCTF had the highest mean score of 3.90, while the ability to access funding from all possible sources had the lowest mean score of 3.16. Other indicators such as innovation in fund sourcing as well as increase in the number of fund sources both had equal mean scores of 3.41.

\subsection{Assessing fund governance and allocation}

Fund governance and management has to do with the decision making processes and the capacity to make those decision adequately and efficiently. This is crucial for an institution such as the ICCTF as it affects donors' confidence (Nakhooda, 2013; Halimanjaya et al., 2014). The strongest component of the ICCTF among the five identified components is fund allocation and disbursement with an index score of 4.015. This component comprised of five indicators, among them, indicators for equitable and fair representation of stakeholders and alignment of projects with national climate change priority emerged as the two strongest indicators with mean scores of 4.19 and 4.23 respectively. On the other hand, the indicator for easy access by the most vulnerable to the ICCTF scored the lowest (3.39). This may be due to the numerous bureaucratic processes involved in 
making and approving project proposals as well as disbursing funds for approved projects. Other indicators for independence from donor interests and adequate capacity and skills to manage climate fund had mean scores of 3.74 and 3.90 and respectively. The above results illustrate how effective the ICCTF is in terms of managing and allocating available resources for climate change programs in Indonesia.

\subsection{Assessing monitoring and evaluation}

Monitoring and evaluation (M\&E) holds a key role in understanding what is working and what is not, and how to learn from experience in order to maximize impact. The result of the analysis suggests that monitoring and evaluation of the ICCTF is carried out in a timely manner (mean score of 4.00). This is not unusual, as developmental donors are known to strictly demand timely evaluation as an indicator of success. "Participatory monitoring and evaluation" had the lowest mean score of 3.29, while "monitoring and evaluation at all levels" scored 3.65. The inference from this is that the ICCTF still operates traditional M\&E approaches with a linear cause-and-effect relationship where a known type of intervention results in a known outcome (Yates, 2014). However, climate change is typically a more complex, long-term, uncertain and unpredictable undertaking requiring alternative and often more innovative M\&E methods, which are not only creative and flexible, but most importantly participatory and multi-scalar in nature (Bours et al., 2015).

\subsection{Assessing accountability and transparency}

Transparent public climate finance management requires key features such as publicly available, complete, accurate and timely information on the institution's financial and funding structure, decision-making processes, actual financing decisions and payments made, as well as results (Schalatek and Bird, 2016). In all these aspects of transparency, the Indonesian Climate Change Trust Fund (ICCTF) is perceived quite highly by experts according to results of this study. Transparency and accountability ranked second out of the 5 components assessed in this study with an overall index score of 3.727. Among the different indicators, the lowest mean score is 0.345 for "existence of a complaint and feed back system". Although the ICCTF has made efforts to improve this aspect with reporting and whistle-blowing mechanisms publicized on its official website, this development is possibly not widely known by the public and by a portion of the experts who took part in this study. Thus, more effort is required to improve this aspect of transparency and accountability. Further simplification of the mechanisms of reporting and filing complaints might be called for, especially as the activities of the ICCTF often include local people who may not feel favored by traditional bureaucratic procedures.

\section{Discussion}

As highlighted in the results above, the ICCTF has a specific legal framework upon which it operates. Although the aim of the legal framework is to ensure accountability and transparency of the ICCTF as a government funded agency, it has significantly constrained the flexibility of the ICCTF in mobilizing funds from a wider variety of entities such as the Adaptation Fund (AF) and other multilateral climate financing institutions. The ICCTF was established by Ministerial Decree 59/M.PPN/HK/09/2010. In order to implement the provision of Article 47 Subsection (2) of Government Regulation No. 10/2011 on Procedure for the Provision of Foreign Loans and Grants, the Presidential Regulation No. 80 year 2011 on Trust Fund was enacted. This regulation clarifies the governance and management of trust funds and developmental aid funding in Indonesia. However, A provision in the regulation affirms that a trust fund is established as a working unit (Satker) under a parent ministry or agency. Going by this provision, trust funds clearly become part of the parent ministry/agency within which they are established, implying that the Board of Trustees (BOT) of the Indonesian Climate Change Trust Fund (ICCTF) do not have legal independence or powers to enter 
into any sort of contracts with a third party. In general, these results suggest that the legal framework of the ICCTF is still below optimum to effectively operate as a National Climate Finance Institution. This is accordance with the assertions of Halimanjaya et al. (2014) that "the legal operationalization of the ICCTF has been a much slower process than anticipated, and providing assurance that the Fund can meet international standards for fiduciary management, environmental and social safeguards, and results management, has been challenging". However, this situation is expected to improve in the future as the ICCTF aims to become an accredited National Implementing Entity (NIE) making it eligible to access funds from wider variety of international funds such as the Adaptation Fund amongst others.

In terms of sustainable mobilization of funds, our results indicate that the ICCTF operates through known and secured funding sources, however, it is less effective in exploring newer and innovative sources of funds both within and outside Indonesia. The ICCTF currently gets the largest share of its funds from the annual budget, while the bulk of the foreign funds have so far been from bilateral sources as products of agreements with donor countries cooperation agencies such as USAID, UKCCU, SIDA, JICA, and AUSAID and multilateral funds coming from the UNDP. Compared to bilateral aid, multilateral aid is known to be less political, delivers better outcomes, and is able to impose more effective conditions (Findley et al., 2017; Girod, 2008). Although designed to be an implementing entity for multilateral funds such as the Adaptation Fund, GEF, GCF etc., the ICCTF is yet to access funds from these institutions mainly due to legal hindrances discussed earlier. Other domestic sources of funding, especially through private enterprises and partnerships, are also yet to be adequately harnessed by the ICCTF. No doubt, abundant and sustained funding is a key indicator of how effective a national climate finance institution is and various international conventions, particularly the Bali Action Plan have emphasized the need for adequate, predictable, sustainable, as well as additional funding to combat climate change (Richards and Schalatek, 2017).

Regarding fund management and allocation decisions and representation, results in this study have indicated an effective fund governance and disbursement system by the ICCTF. Generally, the allocation strategy of the ICCTF appears to be largely influenced by Indonesian national climate change and development priorities even with limited resources, this is highly commendable since the ICCTF was established for that. All relevant stakeholders such as the government, academics, the private sector and the civil society organization (CSOs) are represented within the ICCTF's board of trustee, the major foreign donors to the ICCTF, i.e. USAID, DANIDA, UKCCU and GIZ are also represented with single individual votes. This arrangement helps to significantly minimize the power that donors have over allocation and spending priorities. However, the ICCTF's current steering committee consists of total 13 members, out of which six are government representatives. This practice contrasts with what Spergel and Taieb (2009) described as the best practice for good administration of a developmental fund, according to them, funds with minority government influence are more transparent and efficient in achieving their aims, less affected by political fluctuations and instability, and attracting more international aid as well as private sector investments. However, global best practices do not always equate to effective practices, especially in achieving country level development outcomes (Booth, 2012). Also, ensuring that finance for climate change actions is easily accessible by the most vulnerable people at the local level, where the brunt of climate change is most pronounced, is very important for effective climate change governance (Colenbrander et al., 2018).

As for the availability of information for external and independent evaluation of the ICCTF, our results have shown some improvement. This is another important aspect of our study, because the ICCTF failed to get accredited to access funds from the Adaptation Fund following its nomination by the Indonesian government, due to fear of lack of transparency (Harmeling and Kaloga, 2011 and Liebel et al., 2015). However, since then, external auditing and more involvement of civil society groups in the activities of the ICCTF, have both contributed to enhance transparency of the ICCTF 
(Halimanjaya et al., 2014), and an accreditation is largely anticipated which will further increase the ICCTFs fund sources.

\section{Conclusion}

Adapting to the adverse impacts of climate change as well as mitigating future occurrences is no doubt a key pillar of sustainable development requiring huge financial investments in the hundreds of billions of dollars. At the moment, the availability of finance and ability to gather, coordinate and utilize resources vary widely across countries. In most cases, poor developing countries lack not just the financial power, but more importantly the institutional capacity and skills to adequately participate in the climate finance arena. These weaknesses if left unresolved could significantly slow global progress or even exacerbate underlying problems such as poverty and inequality. Continuous and systematic evaluations are needed to identify critical gaps and enable improvement. This study has identified the legal and regulatory framework, fund mobilization and sustainability, fund governance and allocation, monitoring and evaluation and accountability and transparency as the five principal components of an effective NCFI.

Regarding the legal and regulatory framework, our finding makes it clear that the ICCTF enjoys strong legitimacy within Indonesia, based on the strong legal foundation upon which it was established. However, the ICCTF's legal and regulatory framework is focused more on monitoring to check corruption and enhance transparency, but lacks flexibility to enhance its operation and overall effectiveness. The legal and regulatory framework plays a fundamental role not just for legitimacy, but also in the overall operationalization of the institution, with close link to fund mobilization, fund disbursement as well as accountability and transparency. To achieve sustainable development through climate change governance, it is important to have this broad view of the role of the legal framework in the effectiveness of public institutions. On this basis, it is therefore imperative that the ICCTF be concretely reformed to adequately address these challenges. This includes developing a clear and flexible legal and regulatory framework that will enhance the ICCTF's fund mobilization and disbursement capacity, while maintaining an acceptable level of transparency as well as defining its role and relationships with other relevant players in the climate finance architecture in Indonesia, well beyond the Ministry of National Development Planning (Bappenas).

The ICCTF is presently underfunded owing to the inability to access a wide range of international funds. The majority of its funding comes from the annual budget (APBN), but APBN has numerous outlets aside from the ICCTF for disbursing funds for climate change activities. The sustainability of public institutions in effectively financing sustainable development significantly depends on their ability to mobilize resources efficiently from various sources to avoid over reliance on budgetary supports, which are often vulnerable to economic fluctuations especially in developing countries. There is the need for significant modifications to enable the ICCTF access funds from a wider range of sources such as the Adaptation Fund, the Global Environmental Facility and other international sources of climate finance including innovative sources of finance such as revolving funds, payment for environmental services, equities and private partnerships. However, the ICCTF has been effective in managing and allocating existing funding, it has managed to modestly utilize limited funding available to implement adaptation programs in line with national policy pathways and with good representation of stakeholders. The participation and involvement of key stakeholders at various levels have also enhanced accountability and transparency within the ICCTF.

Finally, while this framework does not offer an encompassing evaluation, our findings enable policy makers to get a wider overview of what is required to effectively plan for, attract, manage and utilize climate finance at the national level both within Indonesia and beyond. This is true especially in the case of the Indonesia, where plans to establish a new environmental fund are underway. It should however be understood that climate change governance like any branch of public policy is to a great extent dictated by the political landscapes of countries. This in turn impacts 
the effectiveness and success of institutions regardless of how well they have been initially designed. More research on the underlying political context of a country and its impact on climate finance effectiveness will therefore help to gain a better insight to the "whys" and "hows" of climate finance effectiveness in various countries. Another limitation of this study relevant for future research is that it does not investigate the interrelationships that often exist among indicators and components, and how these relationships interacts to influence the performance of individual component as well as the overall effectiveness of the system. Future studies may take a closer look into these relationships, as well as a focus on individual components to enable a deeper understanding of how they operate.

Competing interests: The authors declare that they have no competing of interests.

\section{Acknowledgments}

The authors send their sincere gratitude and acknowledgement to the Government of Indonesia for providing a scholarship opportunity at IPB University Bogor, through the "Kemitraan Negara Berkembang" (KNB) as well as the Southeast Asian Regional Center for Graduate Study and Research in Agriculture (SEARCA) for providing a grant. We further acknowledge the support of the DIPI-LPDP and the UK Economic and Social Research Council (ESRC) [grant ES/K006576/1] from the Center for Climate Change Economics and Policy (CCCEP). We also appreciate the immense support and cooperation of the staff and secretariat of the Indonesian Climate Change Trust Fund especially Mr. Sudaryanto, who together with other staff have been very helpful for this study. In addition, we also thank Dr. Ari Mochamad (USAID) for his helpful insights, and all the key persons who took part in this study.

\section{References}

Adger, W. N., Arnell, N. W., \& Tompkins, E. L. (2005). Successful adaptation to climate change across scales. Global environmental change, 15(2), 77-86. doi: https://doi.org/10.1016/j.gloenvcha.2004.12.005

Ameyaw, E.E, \& Chan, A.P.C. (2015). Risk allocation in public-private partnership water supply projects in Ghana, Construction Management and Economics. Routledge, 33(3). 187-208. doi: https://doi.org/10.1080/01446193.2015.1031148

Ayers, J., Huq, S., Wright, H., Faisal, A. M., \& Hussain, S. T. (2014). Mainstreaming climate change adaptation into development in Bangladesh. Climate and Development, 6(4), 293-305. doi: https://doi.org/10.1080/17565529.2014.977761

Ayers, J, \& Dodman, D. (2010). Climate change adaptation and development I: The state of the debate. Progress in Development Studies, 10(2), 161-168. doi: https://doi.org/10.1177/146499340901000205

Barrett, S. (2014). Subnational Climate Justice? Adaptation Finance Distribution and Climate Vulnerability. World Development, https://doi.org/10.1016/j.worlddev.2014.01.014

(58) 130-142. doi:

Barrett, S. (2013). Local level climate justice? Adaptation finance and vulnerability reduction. Global Environmental Change, 23(6), 1819-1829. doi: https://doi.org/10.1016/j.gloenvcha.2013.07.015

Biermann, F., \& Gupta, A. (2011) Accountability and legitimacy in earth system governance: a research framework. Ecological Economics, (70)11. 1856-1864. doi: https://doi.org/10.1016/j.ecolecon.2011.04.008

Bird, N., Tilley, H., Canales, T. Trujillo, N., Tumushabe, G., Welham, B., \& Yanda, P. (2013). Measuring the effectiveness of public climate finance delivery at the national level. London: Overseas Development Institute. Available at: http://www.odi.org.uk/publications/7342measuringeffectiveness-public-climate-finance-delivery-national-domestic-level 
Bladon, A., Mohammed, Y., \& Milner-Gulland, E.J. (2014). A Review of Conservation Trust Funds for Sustainable Marine Resources Management: Conditions for Success. A working paper produced by IIED's Sustainable Markets Group. London, UK. Retrieved from www.iied.org@iiedwww.facebook.com/thellEDhttp://pubs.iied.org/16574IIED

Booth, D. (2012). Aid effectiveness: Bringing country ownership (and politics) back in. Conflict, Security and Develoment, 12(5) 537-558. doi: https://doi.org/10.1080/14678802.2012.744184

Bours, D., McGinn, C., \& Pringle, P. (2015) 'Editors' note. Monitoring and Evaluation of Climate Change Adaptation: A Review of the Landscape'. New Directions for Evaluation.(147), 1-12. doi: https://doi.org/10.1002/ev.20127

Bowman, M., \& Steenmans, K. (2018) Climate Finance Law: legal readiness for climate finance. Report and Findings of Workshop held at King's College London 9-11 March 2018. London, UK: King College.

Bowman, M., \& Steenmans, K. (2019). Legal Readiness for Climate Finance: Private Sector Opportunities. Report and Findings of Roundtable held at King's College London, 25 January 2019. London: King's College London.

Brooks, N., \& Fisher, S. (2013). TAMD - tracking adaptation and measuring development: A step-bystep guide. London, UK: International Institute for Environment and Development.

Buchner, B., \& Wilkinson, J. (2012) 'Public Climate Finance : A Survey of Systems to Monitor and Evaluate Climate Finance Effectiveness'. London, Uk: Climate Policy Initiative, pp. 10-12

Chaum, M., Faris, C., Wagner, G., \& Brown, J. (2011). Improving the Effectiveness of Climate Finance: Key Lessons. Washington DC: Brookings Institute

Christiansen, L., Ray, A. D., Smith, J. B., \& Haites, E. (2012). Accessing International Funding for Climate Change Adaptation. A Guidebook for Developing Countries. TNA Guidebook Series. UNEP Ris $\varnothing$ Centre on Energy, Climate and Sustainable Development, Rosklide, Denmark.

Colenbrander, S., Dodman, D., \& Mitlin, D. (2018). Using climate finance to advance climate justice: the politics and practice of channelling resources to the local level. Climate Policy, 18(7) 902915. doi: https://doi.org/10.1080/14693062.2017.1388212

Denton, F. (2010). Financing adaptation in Least Developed Countries in West Africa: is finance the 'real deal'? Climate Policy, 10 (6) 655-671. doi: https://doi.org/10.3763/cpol.2010.0149

Di Gregorio, M., Fatorelli, L., Paavola, J., Locatelli, B., Pramova, E., Nurrochmat, D.R., May, P.H., Brockhaus, M., Sari, I.M., \& Kusumadewi, S.D. (2019). Multi-level Governance and Power in Climate Change Policy Networks. Global Environmental Change, (54) 64-77. doi: https://doi.org/10.1016/j.gloenvcha.2018.10.003

Di Gregorio, M., Nurrochmat, D.R., Paavola, J., Sari, I.M., Fatorelli, L., Pramova, E., Locatelli, B., Brockhaus, M., \& Kusumadewi, S.D. (2017). Climate policy integration in the land use sector: Mitigation, adaptation and sustainable development linkages. Environmental Science \& Policy, 67, 35-43. doi: https://doi.org/10.1016/j.envsci.2016.11.004

Dore, J., \& Lebel, L. (2010). Gaining public acceptance: a critical strategic priority of the World Commission on Dams, Water Alternatives, 3 (2) 154-171.

Douxchamps, S., Debevec, L., Giordano, M., \& Barron, J. (2017). Monitoring and evaluation of climate resilience for agricultural development -A review of currently available tools. World Development Perspectives, (5)10-23. doi: https://doi.org/10.1016/j.wdp.2017.02.001

Erbaugh, J. T., \& Nurrochmat, D. R. (2019). Paradigm shift and business as usual through policy layering: Forest-related policy change in Indonesia (1999-2016). Land use policy, 86, 136-146. doi: https://doi.org/10.1016/j.landusepol.2019.04.021

Ellis, J., Caruso, R., \& Ockenden, S. (2013). Exploring Climate Finance Effectiveness. Climate Change Expert Group Paper No. 2013(4). Paris: OECD. 
Fankhauser, S., \& Burton, I. (2011). Spending adaptation money wisely. Climate Policy, (11)3, 10371049. doi: https://doi.org/10.1080/14693062.2011.582389

Faulkner, L., Ayers, J., \& Huq, S. (2015). Meaningful measurement for community-based adaptation. In D. Bours, C. McGinn, \& P. Pringle (Eds.), Monitoring and evaluation of climate change adaptation: A review of the landscape. New Directions for Evaluation, 147, 89-104.

Findley, M.G., Milner, H.V., \& Nielson D.L. (2017). The choice among aid donors: The effects of multilateral vs. bilateral aid on recipient behavioral support. Review of International Organizations, 12(2), 307-334. doi: https://doi.org/10.1007/s11558-017-9275-2

Flynn, C. (2011). Blending Climate Finance through National Climate Funds: A guidebook for the design and establishment of national funds to achieve climate change priorities. United Nations Development Program. New York, NY: UNDP.

Ford, J. D., Berrang-Ford, L., Biesbroek, R., Araos, M., Austin, S. E., \& Lesnikowski, A. (2015). Adaptation tracking for a post-2015 climate agreement. Nature Climate Change, 5(11), 967969. doi: https://doi.org/10.1038/nclimate2744

Ford, J.D., Berrang-Ford, L., Lesnikowski, A., Barrera, M., \& Heymann, S.J. (2013). How to track adaptation to climate change: a typology of approaches for national-level application. Ecology and Society, 18(3) 40. http://dx.doi.org/10.5751/ES-05732-180340

Fox, J. (2007). The uncertain relationship between transparency and accountability. Development in Practice, (17)4-5, 663-671. doi: https://doi.org/10.1080/09614520701469955

Girod, D. (2008). Cut from the Same Cloth? Multilateral vs. Bilateral Aid. Paper presented at the annual meeting of the International Political Economy Society. Philadelphia, PA

Glemarec, Y. (2011). Catalyzing Climate Finance A Guidebook on Policy and Financing Options to Support Green, Low-Emission and Climate- Resilient Development, United Nations Development Program UNDP, April 2011. New York, NY USA.

Grüning, C., Menzel, C., Shuford, L.S, \&Sonntag-O'Brien, V. (2012). National Climate Finance Institution Support Programme. Case Study: The Indonesia Climate Change Trust Fund (ICCTF). Frankfurt GN: UNEP.

Gupta, A., \& Mason M. (2016). Disclosing or obscuring? The politics of transparency in global climate governance. Current Opinionsin Environmental Sustainability.(11) 1882-90. doi: https://doi.org/10.1016/j.cosust.2015.11.004

Gupta, J., Termeer, C., Klostermann, J., Meijerink, S., van den Brink, M., Jong, P., Nooteboom, S., \& Bergsma, E. (2010). The Adaptive Capacity Wheel: a method to assess the inherent characteristics of institutions to enable the adaptive capacity of society. Environmental Science and Policy (13) 459-471.

Hall, S., Foxon, TJ., \& Bolton, R. (2017). Investing in low-carbon transitions: energy finance as an adaptive market. Climate Policy 17 (3). doi: https://doi.org/10.1080/14693062.2015.1094731

Haasnoot, M., van't Klooster, S., \& Van Alphen, J. (2018). Designing a monitoring system to detect signals to adapt to uncertain climate change. Global Environmental Change, 52, 273-285. doi: https://doi.org/10.1016/j.gloenvcha.2018.08.003

Halimanjaya, A., Nakhooda, S., \& Barnard, S. (2014). The effectiveness of climate finance: a review of the Indonesia Climate Change Trust Fund. Working paper for the Overseas Development Institute. London: ODI.

Hanger, S., Pfenninger, S., Dreyfus, M., \& Patt, A. (2013). Knowledge and information needs of adaptation policymakers: a European study. Regional Environmental Change, (13)91-101. http://dx.doi.org/10.1007/s10113-012-0317-2

Harmeling, S., \& Kaloga, A. (2011). Understanding the political economy of the adaptation fund. IDS Bulletin, Vol. 42, No. 3, pp.23-32. 
Hein, J., Guarin, A., Frommé, E., \& Pauw, P. (2018). Deforestation and the Paris climate agreement: An assessment of REDD+ in the national climate action plans. Forest Policy and Economics, 90, 7-11. doi: https://doi.org/10.1016/j.forpol.2018.01.005

Irawan, S., Heikens, A., \& Kevin, P. (2012). National Climate Funds: Learning from the experience of Asia-Pacific countries. UNDP discussion paper. Washington DC: UNDP.

Kotchen, M.J., \& Costello, C. (2018). Maximizing the impact of climate finance: Funding projects or pilot projects? Journal of Environmental Economics and Management, (92) 270-281. doi: https://doi.org/10.1016/j.jeem.2018.08.009

Lamhauge, N., Lanzi, E., Agrawal, E., \& Agrawala, S. (2012). Monitoring evaluation for adaptation: lessons from development cooperation agencies. OECD Environment Working Papers 38. http://dx.doi.org/10.1787/5kg20mj6c2bw-en

Lebel, L., Salamanca, A., \& Kallayanamitra, C. (2017).The governance of adaptation financing: pursuing legitimacy at multiple levels, International Journal of Global Warming, (11)2.226245. doi: https://doi.org/10.1504/IJGW.2017.082181

Lesnikowski, A., Ford, J., Biesbroek, R., Berrang-Ford, L., Maillet, M., Araos, M., \& Austin, S. E. (2017). What does the Paris Agreement mean for adaptation?. Climate Policy, 17(7), 825-831. doi: https://doi.org/10.1080/14693062.2016.1248889

Mehrotra, S. (2006). Governance and basic social services: ensuring accountability in service delivery through deep democratic decentralization. Journal of International Development: The Journal of the Development Studies Association, 18(2), 263-283. doi: https://doi.org/10.1002/jid.1219

Molenaers, N., Dellepiane, S., \& Faust, J. ( 2015). Political Conditionality and Foreign Aid. World Developent 75(8):2-12. doi: http://dx.doi.org/10.1016/j.worlddev.2015.04.001.

Morita, T., \& Pak, C. (2018). Legal readiness to attract climate finance: Towards a low-carbon Asia and the Pacific. CCLR, 6.

Moss, R.H., Meehl, G.A., Lemos, M.C., Smith, J.B., Arnold, J.R., Arnott, J.C., Behar,D., Brasseur, G.P., Broomell, S.B., \& Busalacchi, A.J. (2013). Hell and high water: practice-relevant adaptation science. Science, 342(6159), 696-698. doi: http://dx.doi.org/10.1126/science.1239569

Nakhooda, S., \& Amin, A.L. (2013). The effectiveness of climate finance: a review of the Clean Technology Fund. Working paper for the Overseas Development Institute (ODI). March. London: ODI.

Nakhooda, S. (2013). The effectiveness of international climate finance. Working Paper 371 Results of ODI research presented in preliminary form for discussion and critical comment. London UK: ODI.

Nakhooda, S., \& Watson, C. (2019). The Global Climate Finance Architecture. Climate Funds Update, Overseas Development institute ODI. London UK.

Nakhooda, S., Norman, S., Barnard, S., Greenhill, R., Caravani, A.T., \& Banton, G. (2014). Climate Finance: Is It Making a Difference? A Review of the Effectiveness of Multilateral Climate Funds. London: Overseas Development Institute.

Nelson, R., Kokic, P., Crimp, S., Martin, P., Meinke, H., Howden, S.M., de Voil, P., \& Nidumolu, U. (2010). The vulnerability of Australian rural communities to climate variability and change. Part II. Integrating impacts with adaptive capacity. Environmental Science and Policy, (13) 18 27. doi: https://doi.org/10.1016/j.envsci.2009.09.007

Nicholson, K., Beloe, T., \& Hodes, G. (2017). Hard Choices Integrated Approaches: A Guidance Note on Climate Change Financing Frameworks. United Nations Development Program (UNDP).

Norman, M., \& Nakhooda, S. (2015). The state of REDD+ Finance. In: CGD Climate and Forest Paper Series \#5. Washington, D.C.: Center for Global Development. 
Norris, R. (2000). The IPG Handbook on Environmental Funds. A resource book for design and operation of environmental funds, New York: PACT Publications. Available at: www.geocities.com/shores_system/ef/ef_handbook.html

Nurrochmat, D. R., Boer, R., Ardiansyah, M., Immanuel, G., \& Purwawangsa, H. (2020). Policy forum: Reconciling palm oil targets and reduced deforestation: Landswap and agrarian reform in Indonesia. Forest Policy and Economics, 119, 102291. doi: https://doi.org/10.1016/j.forpol.2020.102291

Olazabal, M., Galarraga, I., Ford, J., De Murieta, E.S., \& Lesnikowski, A. (2019). Are local climate adaptation policies credible; A conceptual and operational assessment framework. International Journal of Urban Sustainable Development. 11(3)277-296, doi: https://doi.org//10.1080/19463138.2019.1583234

Owusu, E.K., Chan, A.C., Yang, J., \& Parn, E. (2020). Towards corruption-free cities: Measuring the effectiveness of anti-corruption measures in infrastructure project procurement and management in Hong Kong', Cities, 96 (August 2019), p. 102435. doi: https://doi.org/10.1016/j.cities.2019.102435

Peters, I., Christoplos, I., Funder, M., Friis-Hansen, E., \& Pain, A. (2012). Understanding institutional change: a review of selected literature for the climate change and rural institutions research program. DIIS Working Paper 2012.12. Copenhagen: Danish Institute for International Studies.

Preston, B. L., Rickards, L., Fünfgeld, H., \& Keenan, R. J. (2015). Toward reflexive climate adaptation research.Current opinion in environmental sustainability, 14, 127-135. doi: https://doi.org/10.1016/j.cosust.2015.05.002

Preston, B.L., Westaway, R.M., \& Yuen, E.J. (2011). Climate adaptation planning in practice: an evaluation of adaptation plans from three developed nations. Mitigation and Adaptation, Strategies for Global Change, (16) 407-438. doi: https://doi.org/10.1007/s11027-010-9270-x

Rai, N., Kaur, N., Greene, S., Wang, B., \& Steele, P. (2015). A Guide to National Governance of Climate Finance. International Institute for Environment and Development (IIED). London, Uk. DOI: http://dx.doi.org/10.12774/eod_tg.march2015.rainetal

Richards, J., \& Schalatek, L. (2017). Financing Loss \& Damage. A Look at Governance and Implementation Options. Heinrich Böll Stiftung, Washington, DC. Available at: https://www.boell.de/sites/default/files/loss_and_damage_finance_paper_update_16_may _2017.pdf?dimension1=division_oen

Runhaar, H., Driessen, P., \& Uittenbroek, C. (2014). Towards a systematic framework for the analysis of environmental policy integration. Environmental Policy and Governance, 24 (4), 233-246. doi: http://dx.doi.org/10.1002/eet.1647

Samuwai, J., \& Hills, J.M. (2018). Assessing Climate Finance Readiness in the Asia-Pacific Region. Sustainability, (10) 1192; doi: 10.3390/su10041192

Sahide, M. A. K., Nurrochmat, D. R., \& Giessen, L. (2015). The regime complex for tropical rainforest transformation: Analysing the relevance of multiple global and regional land use regimes in Indonesia. Land Use Policy, 47, 408-425. doi: http://dx.doi.org/10.1016/j.landusepol.2015.04.030

Schalatek, L., \& Bird, N. (2016). The Principles and Criteria of Public Climate Finance - A Normative Framework. Climate Funds Update (CFU)/Climate Finance Fundamentals 1, November 2016. Hbs North America: ODI.

Schipper, L. (2007). Climate change adaptation and development: Exploring the linkages. Tyndall Centre Working Paper Series 107. Norwich, UK. Tyndall Centre for Climate Change Research.

Scobie, M. (2016). Policy coherence in climate governance in Caribbean small island developing states. Environmental Science \& Policy, 58, 16-28. doi: https://doi.org/10.1016/j.envsci.2015.12.008 
Smyth, S. (2009). A practical guide to creating a collective financing effort to save the world: The global environment facility experience. Geo. Int'l Envtl. L. Rev., 22, 29.

Smyth, S. (2011). Agency and Accountability in Multilateral Development Finance: An Agenda for Change. The Law and Development Review: 4(1). doi: https://doi.org/10.2202/19433867.1113

Spergel, B., \& Taïeb, P. (2008). Rapid Review of Conservation Trust Funds, Prepared for the CFA Working Group on Environmental Funds. Conservation Finance Alliance (CFA), Washington DC, USA.

Tavakol, M., \& Dennick, R. (2011). Making sense of Cronbach's alpha, International Journal of Medical Education, (2)53-55. doi: https://doi.org/10.5116/ijme.4dfb.8dfd

Tippmann, R., Agoumi, A., Perroy, L., Doria, M., Henders, S., \& Goldmann, R. (2013). Assessing barriers and solutions to financing adaptation projects in Africa. A report submitted to the International Development Research Centre. Toronto: International Development Research Centre.

Vanderweerd, V., Glemarec, Y., \& Billett, S. (2014). Readiness for Climate Finance: A Framework for Understanding What It Means to Be Ready to Use Climate Finance. United Nations Development Program 2014; pp. 1-28. New York, NY: UNDP.

Vij, S., Moors, E., Ahmad, B., Arfanuzzaman, M.D., Bhadwal, S., Biesbroek, R., Gioli, G., Groot, A., Mallick, D., Regmi, B., Saeed, B.A., Ishaq, S., Thapa, B., Werners, S.E., \& Wester, P. (2017). Climate adaptation approaches and key policy characteristics: Cases from South Asia. Environmental Science and Policy, (78)58-65.

Watson, C., \& Schalatek, L. (2019). The Global Climate Finance Architecture. Climate Finance Fundamentals 2 Overseas Development Institute. February. London: ODI.

Weiler, F., Klöck, C., \& Dornan, M. (2018). Vulnerability, good governance, or donor interests? The allocation of aid for climate change adaptation. World Development, 104, 65-77. doi: https://doi.org/10.1016/j.worlddev.2017.11.001

Yates, J.S. (2014). Power and politics in the governance of community-based adaptation. In: J. Ensor, R. Berger, \& Huq, S. (Eds.). Community-based adaptation to climate change: Emerging lessons. Rubgy, United Kingdom: Practical Action Publication. 
Appendix 1. Result of multicriteria decision analysis of the five components

\begin{tabular}{|c|c|c|c|c|c|c|c|c|c|c|}
\hline \multirow{2}{*}{$\begin{array}{l}\text { Components/ Indicators } \\
\text { Legal and regulatory } \\
\text { framework }\end{array}$} & \multirow{2}{*}{$\begin{array}{l}\text { Mean } \\
\text { score } \\
\text { (M) }\end{array}$} & \multirow{2}{*}{$\begin{array}{l}\text { Indicator } \\
\text { weight } \\
\text { (W) }\end{array}$} & \multirow{2}{*}{$\begin{array}{l}\text { Compo } \\
\text {-nent } \\
\text { weight }\end{array}$} & \multicolumn{5}{|c|}{ Components' membership scores (D) } & \multirow{2}{*}{$\begin{array}{l}\text { Index } \\
\text { score (I) }\end{array}$} & \multirow{2}{*}{$\begin{array}{l}\text { Ran } \\
k\end{array}$} \\
\hline & & & & & & & & & & \\
\hline $\begin{array}{l}\text { Laws allow efficient } \\
\text { disbursement and allocation. }\end{array}$ & 3.42 & 0.186 & 0.237 & 0.000 & 0.043 & 0.335 & 0.494 & 0.128 & 3.705 & 3 \\
\hline $\begin{array}{l}\text { Laws and regulations are not } \\
\text { contradictory or overlap with } \\
\text { other institutions. }\end{array}$ & 3.58 & 0.195 & & & & & & & & \\
\hline $\begin{array}{l}\text { Clarity of laws and regulations } \\
\text { governing the Fund. }\end{array}$ & 3.97 & 0.216 & & & & & & & & \\
\hline $\begin{array}{l}\text { Laws enable maximum and } \\
\text { efficient mobilization of fund }\end{array}$ & 3.29 & 0.179 & & & & & & & & \\
\hline $\begin{array}{l}\text { Laws and regulations enhance } \\
\text { transparency and accountability } \\
\text { of the ICCTF. }\end{array}$ & 4.13 & 0.225 & & & & & & & & \\
\hline \multicolumn{11}{|l|}{$\begin{array}{l}\text { Fund mobilization and } \\
\text { sustainability }\end{array}$} \\
\hline $\begin{array}{l}\text { Sources of fund are known and } \\
\text { secured over long term funding } \\
\text { cycle. }\end{array}$ & 3.90 & 0.281 & 0.179 & 0.000 & 0.048 & 0.448 & 0.463 & 0.041 & 3.497 & 5 \\
\hline $\begin{array}{l}\text { Fund is sourced from all } \\
\text { possible sources. }\end{array}$ & 3.16 & 0.227 & & & & & & & & \\
\hline Innovation in sourcing fund & 3.42 & 0.246 & & & & & & & & \\
\hline $\begin{array}{l}\text { Fund and its sources are } \\
\text { increasing. }\end{array}$ & 3.42 & 0.246 & & & & & & & & \\
\hline \multicolumn{11}{|l|}{$\begin{array}{l}\text { Fund governance and } \\
\text { allocation }\end{array}$} \\
\hline $\begin{array}{l}\text { Equitable and fair } \\
\text { representation of stakeholders }\end{array}$ & 4.19 & 0.215 & 0.250 & 0.000 & 0.011 & 0.214 & 0.584 & 0.191 & 4.015 & 1 \\
\hline $\begin{array}{l}\text { Independence from donor } \\
\text { interest/pressure }\end{array}$ & 3.74 & 0.192 & & & & & & & & \\
\hline $\begin{array}{l}\text { Adequate capacity and skill to } \\
\text { manage climate fund }\end{array}$ & 3.90 & 0.200 & & & & & & & & \\
\hline $\begin{array}{l}\text { Easily accessible to the most } \\
\text { vulnerable }\end{array}$ & 3.39 & 0.174 & & & & & & & & \\
\hline $\begin{array}{l}\text { Supports and align with national } \\
\text { climate change priorities }\end{array}$ & 4.23 & 0.217 & & & & & & & & \\
\hline \multicolumn{11}{|l|}{ Monitoring and evaluation } \\
\hline $\begin{array}{l}\text { Monitoring and evaluation of } \\
\text { projects is participatory }\end{array}$ & 3.29 & 0.301 & 0.141 & 0.000 & 0.019 & 0.360 & 0.554 & 0.067 & 3.668 & 4 \\
\hline $\begin{array}{l}\text { Monitoring and evaluation } \\
\text { exercise is timely }\end{array}$ & 4.00 & 0.366 & & & & & & & & \\
\hline $\begin{array}{l}\text { Monitoring and evaluation is } \\
\text { carried out at all levels }\end{array}$ & 3.65 & 0.333 & & & & & & & & \\
\hline \multicolumn{11}{|l|}{$\begin{array}{l}\text { Transparency and } \\
\text { accountability }\end{array}$} \\
\hline $\begin{array}{l}\text { Timely and public disclosure of } \\
\text { all earnings and spending }\end{array}$ & 3.84 & 0.259 & 0.191 & 0.023 & 0.039 & 0.223 & 0.614 & 0.099 & 3.727 & 2 \\
\hline $\begin{array}{l}\text { Transparent allocation and } \\
\text { disbursement procedures }\end{array}$ & 4.06 & 0.274 & & & & & & & & \\
\hline $\begin{array}{l}\text { Existence of a complaint and } \\
\text { feedback system }\end{array}$ & 3.45 & 0.233 & & & & & & & & \\
\hline $\begin{array}{l}\text { Public access to information for } \\
\text { independent evaluation }\end{array}$ & 3.48 & 0.235 & & & & & & & & \\
\hline
\end{tabular}

